\title{
PROGRAM \\ FÖR ARBETSLIV
}

Sveriges ordförandeskap 2018

(11) Nordiska ministerrådet

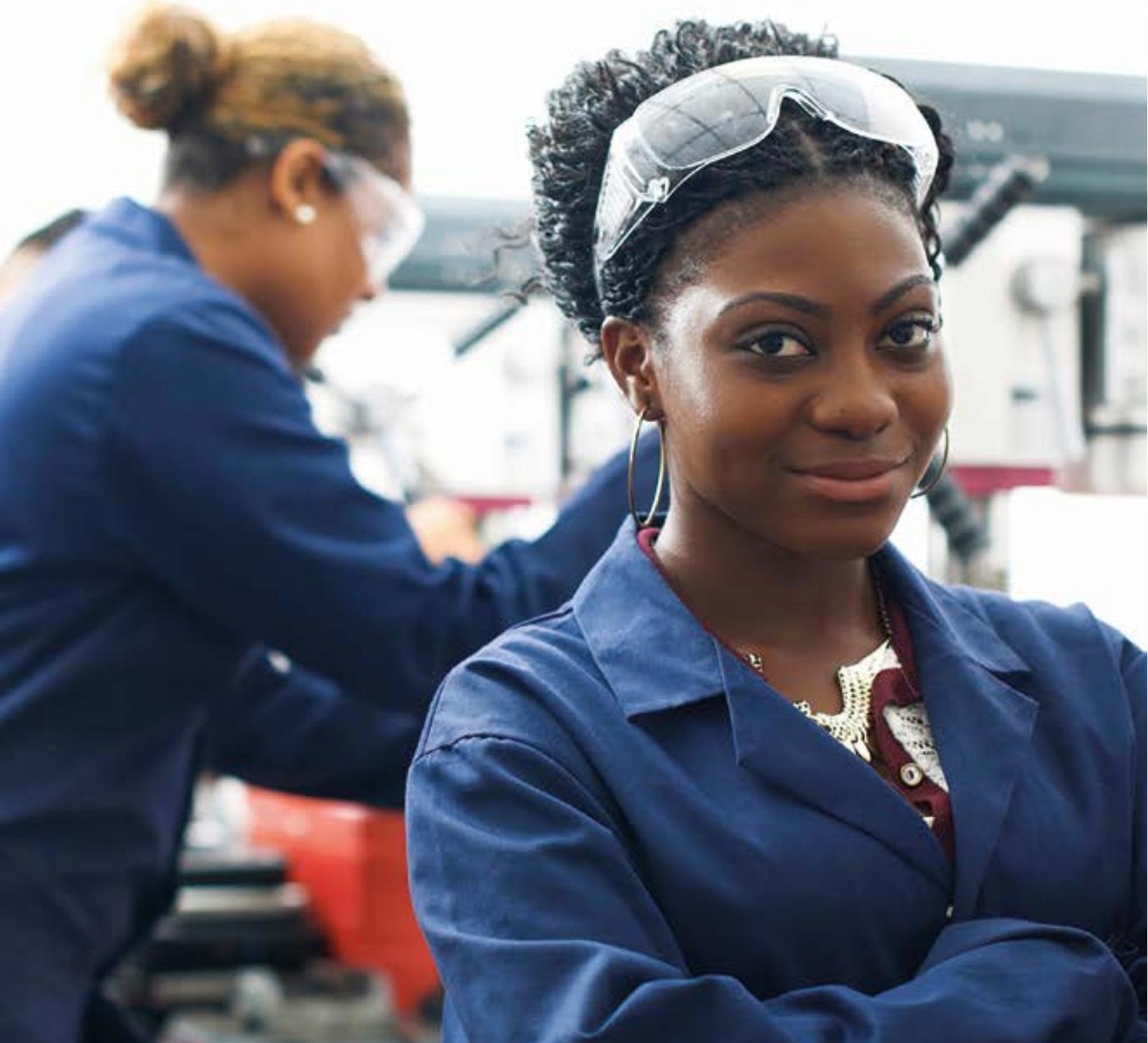

Med fokus på framtiden och en väl fungerande arbetsmarknad 


\title{
Program för arbetsliv
}

Sveriges ordförandeskap 2018 i Nordiska ministerrådet

\author{
ANP 2017:784 \\ ISBN 978-92-893-5277-2 (PRINT) \\ ISBN 978-92-893-5278-9 (PDF) \\ ISBN 978-92-893-5279-6 (EPUB) \\ http://dx.doi.org/10.6027/ANP2017-784 \\ (c) Nordiska ministerrådet 2017 \\ Layout: Gitte Wejnold \\ Omslagsfoto: Folio
}

\section{Det nordiska samarbetet}

Det nordiska samarbetet är ett av världens mest omfattande regionala samarbeten. Det omfattar Danmark, Finland, Island, Norge och Sverige samt Färöarna, Grönland och Åland.

Det nordiska samarbetet är politiskt, ekonomiskt och kulturellt förankrat och en viktig del av europeiskt och internationellt samarbete. Den nordiska gemenskapen arbetar för ett starkt Norden i ett starkt Europa.

Det nordiska samarbetet vill styrka nordiska och regionala intressen och värderingar i en global omvärld. Gemensamma värderingar länderna emellan bidrar till att stärka Nordens ställning som en av världens mest innovativa och konkurrenskraftiga regioner.

\section{Nordiska ministerrådet}

Nordens Hus

Ved Stranden 18

1061 København K

www.norden.org

Ladda ner nordiska publikationer: www.norden.org/nordpub 


\section{Innehåll}

Förord av ministern $\quad 5$

Inledning 6

Etablering på arbetsmarknaden med särskilt fokus på kvinnor 8

Framtidens arbetsmarknad 9

$\begin{array}{ll}\text { Ordning och reda på arbetsmarknaden } & 10\end{array}$

$\begin{array}{ll}\text { Den vuxna befolkningens kunskaper och kompetens } & 11\end{array}$

$\begin{array}{ll}\text { Gränshinderarbetet } & 12\end{array}$

$\begin{array}{ll}\text { Ett nytt samarbetsprogram 2018-2021 } & 13\end{array}$

$\begin{array}{ll}\text { Övergripande fokusområde och samarbetspartners } & 14\end{array}$

$\begin{array}{ll}\text { Preliminärt kalendarium } 2018 & 15\end{array}$ 


\section{Förord av ministern}

Sverige tar över ordförandeskapet i

Nordiska ministerrådet i en tid som präglas av stora utmaningar på den nordiska arbetsmarknaden. Samtidigt skapar förändringarna på arbetsmarknaden även nya möjligheter. Hur vi väljer att bemöta dessa kommer att få stor inverkan på det framtida arbetslivet.

Vi kommer under vårt ordförandeår i Nordiska ministerrådet för arbetsliv att särskilt fokusera på hur nyanlända kvinnor och män på ett snabbt sätt kan etablera sig på arbetsmarknaden. Det finns även ett behov av att studera och närmare diskutera hur den teknologiska utvecklingen kommer att påverka den nordiska arbetsmarknaden i framtiden och vad denna kommer att få för konsekvenser för efterfrågan på kompetens och livslångt lärande. Ett nordiskt samarbete kring ordning och reda på arbetsmarknaden kommer även att genomföras under vårt ordförandeår i syfte att verka för goda och rättvisa villkor, en bra arbetsmiljö och sund konkurrens mellan företag.

I mer än 60 år har vi haft en gemensam nordisk arbetsmarknad och den fria rörligheten över gränserna utgör en hörnsten i det nordiska samarbetet. Denna rörlighet hämmas till viss del av olika gränshinder som uppkommer på grund av olika nationella regler och bestämmelser. Det är min förhoppning att vi under 2018 kommer att kunna lösa några av de hinder inom arbetsmarknadsområdet som har koppling till arbetslöshetsförsäkringen.

De nordiska länderna har mycket att vinna på att fortsätta det nära samarbetet inom arbetslivsområdet. Genom att initiera nordiska projekt som bidrar till ny kunskap, ha ett aktivt ömsesidigt erfarenhetsutbyte och skapa mötestillfällen för diskussioner och lärande på olika nivåer kan vi tillsammans bli bättre rustade att möta framtidens arbetsmarknad.

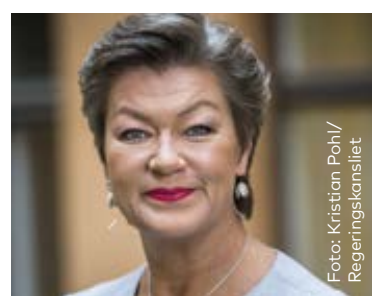

Ylva Johansson

Arbetsmarknads-och etableringsminister 


\section{Inledning}

I en snabbt föränderlig omvärld där faktorer som demografisk utveckling, globalisering och teknologiska framsteg påverkar framtidens arbetsmarknad ställs höga krav på att de nordiska länderna har kapacitet att anpassa sig till nya förhållanden. Teknologins snabba utveckling innebär att vissa arbetsuppgifter försvinner samtidigt som nya tillkommer i spåren av digitalisering, robotisering och automatisering. Den teknologiska utvecklingen har även konsekvenser för arbetets organisering och innehåll och ställer krav på strategier för att utbilda och kompetensutveckla arbetskraft för framtidens arbetsmarknad. Goda möjligheter för arbetstagares omställning kommer även fortsatt att vara en viktig pusselbit på framtidens arbetsmarknad och ställer krav på samarbete mellan företag, individ och stat.

Den demografiska utvecklingen innebär att det framöver kommer att finnas behov av fler personer i arbetskraften. Redan i dag råder brist på arbetskraft inom en rad sektorer och yrken. Den potential som finns bland dem som inte har ett arbete, men som skulle kunna arbeta måste därför tas tillvara. Det gäller inte minst det stora antal nyanlända kvinnor och män som är i yrkesverksam ålder. Arbete är nyckeln till en framgångsrik etablering eftersom det möjliggör egenförsörjning och en utveckling av språkkunskaperna.

Goda villkor för arbetstagare samt rättvis konkurrens för företag är centrala för en väl fungerande arbetsmarknad. Företag som medvetet bryter mot regler för att få konkurrensfördelar skapar osund konkurrens i arbetslivet. För att få god effekt av arbetet mot osund konkurrens och odeklarerat arbete är det viktigt att stärka de nordiska ländernas arbete på området.

För att kunna möta konkurrensen på en mer globaliserad och internationell arbetsmarknad är en avgörande faktor att ha en arbetskraft som besitter de färdigheter och kunskaper som efterfrågas. Det är därför viktigt att kunna bedöma och analysera om den arbetsföra befolkningen i Norden har de kunskaper och den kompetens som krävs på arbetsmarknaden i dag och i framtiden. Validering är en viktig insats i det fortsatta arbetet med detta. 


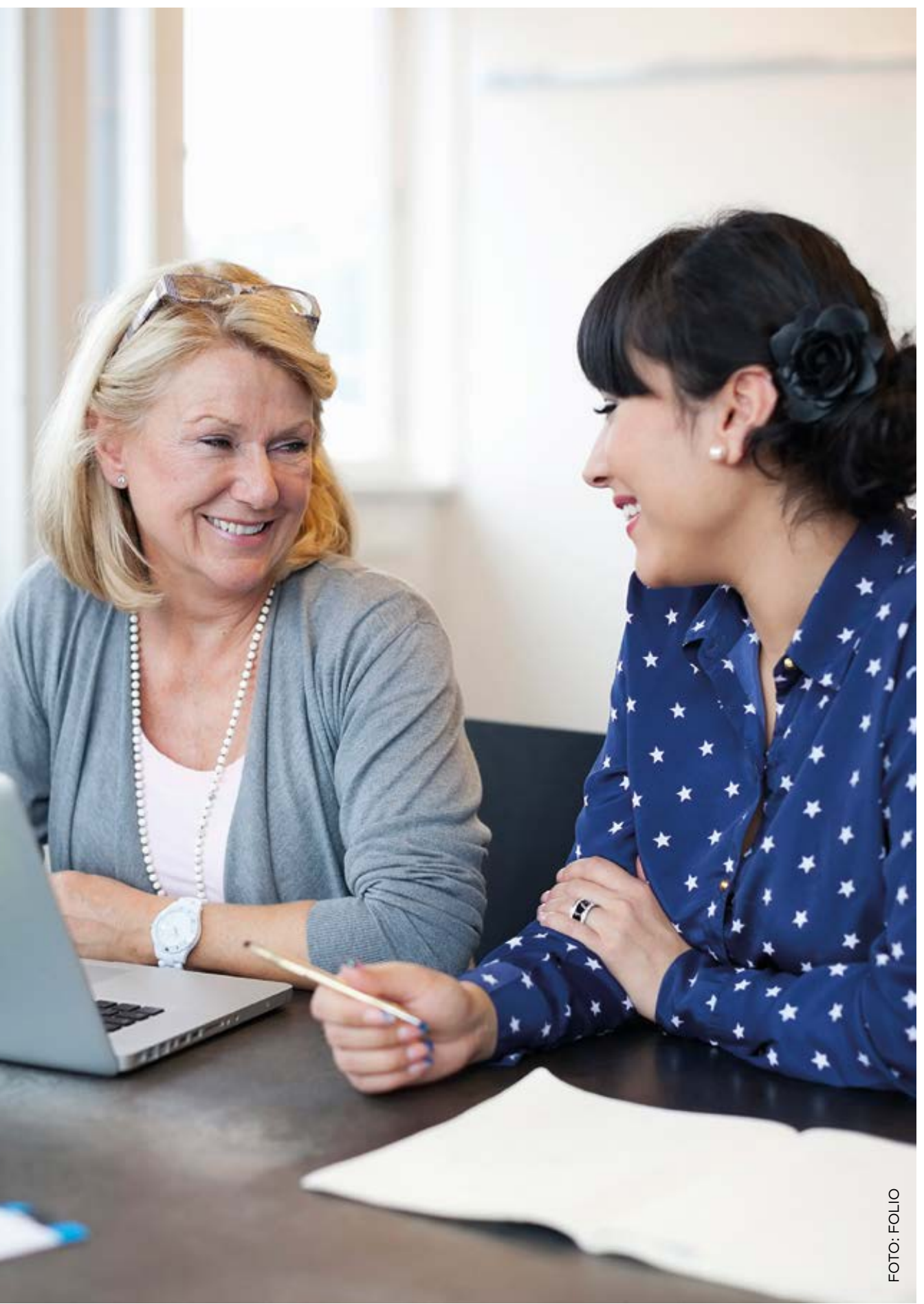




\section{Etablering på arbetsmarknaden med särskilt fokus på kvinnor}

De närmaste åren kommer att präglas av att många nyanlända ska etablera sig i de nordiska samhällena. Denna situation innebär både en utmaning och en möjlighet. Ett fokusområde under det svenska ordförandeskapsåret blir att hitta vägar in på arbetsmarknaden för nyanlända och utrikes födda, framför allt för kvinnor. Många har erfarenheter och kompetenser som efterfrågas på de nordiska arbetsmarknaderna, men som kan behöva valideras och kompletteras.

Internationellt sett har kvinnor i de nordiska länderna ett högt arbetskraftsdeltagande och en hög sysselsättningsgrad. Sysselsättningsgraden bland utrikes födda kvinnor är dock betydligt lägre, även i förhållande till utrikes födda män.
För att etableringen av nyanlända kvinnor ska bli framgångsrik är det viktigt att kvinnor ges samma möjligheter och förutsättningar som män.

Arbetsmarknads- och etableringsminister Ylva Johansson kommer att bjuda in sina nordiska ministerkollegor till en konferens om etablering på arbetsmarknaden för utrikes födda den 13 april 2018. Syftet med konferensen är att presentera aktuell forskning på området, diskutera utmaningar och lämpliga policyåtgärder samt lyfta fram goda exempel på lyckade etableringsinsatser i Norden. Inför konferensen kommer en särskild analysrapport och en kunskapsöversikt över kvinnors etablering att tas fram.
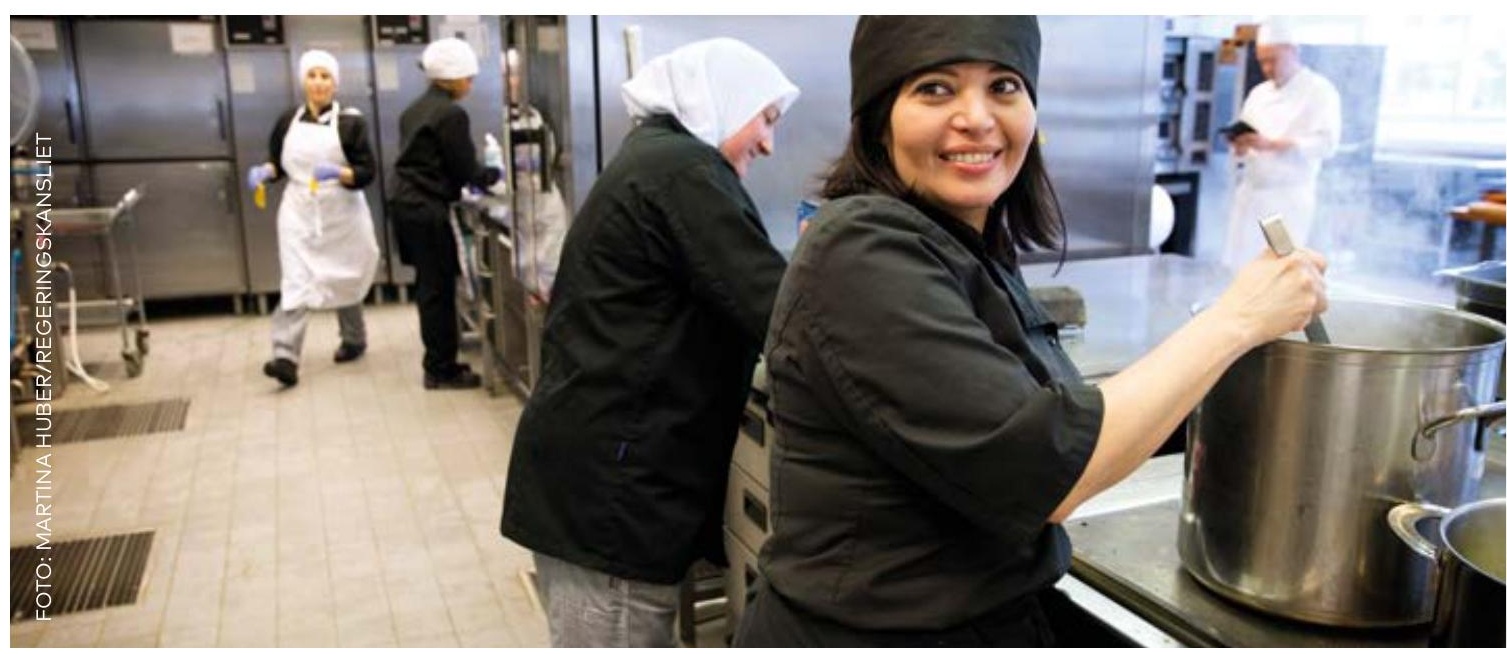


\section{Framtidens arbetsmarknad}

Med anledning av att den Internationella arbetsorganisationen (ILO) firar sitt hundraårsjubileum under 2019 har ILO inför jubileet bland annat valt att fokusera på frågeställningar som rör framtidens arbetsmarknad (Future of Work). Nordiska ministerrådet har involverats i detta arbete och under 2016 startades ett flerårigt projekt som syftar till att fokusera på arbetsmarknadens framtida utveckling. De underlag och rapporter som skapas inom ramen för detta projekt kommer att utgöra ett nordiskt bidrag till ILO:s hundraårsjubileum. Utöver detta projekt har även ett större nordiskt forskningsprojekt kring framtidens arbetsmarknad startat under hösten 2017.
Den 15-16 maj 2018 kommer en konferens om framtidens arbetsmarknad att äga rum i Stockholm. Fokus för konferensen kommer att vara hur den teknologiska utvecklingen i form av digitalisering, robotisering och automatisering kommer att påverka framtidens arbetsmarknad samt vilka konsekvenser detta för med sig för efterfrågad kompetens och behov av livslångt lärande. Under konferensen kommer aktuell forskning om framtidens arbetsmarknad att lyftas fram samt redogörelser för hur nordiska regeringar, myndigheter, företag och arbetsmarknadens parter förbereder sig för framtidens arbetsmarknad att presenteras.

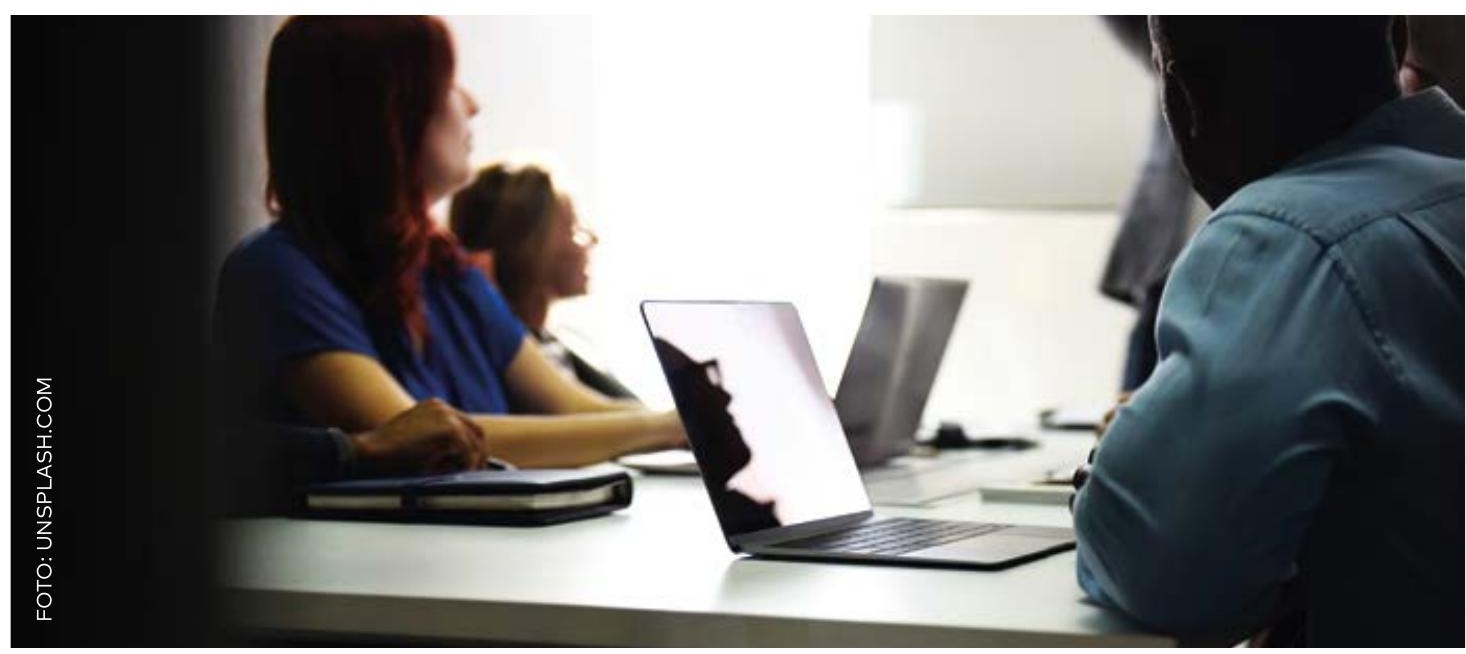




\section{Ordning och reda på arbetsmarknaden}

Vikten av att det råder ordning och reda på arbetsmarknaden är gemensam för de nordiska länderna. Ett företag ska inte riskera att bli utkonkurrerat till följd av att andra företag har undermåliga villkor för sina anställda. Konkurrens ska bygga på kunskap och kompetens - inte på sänkta löner, dåliga arbetsförhållanden eller brister i säkerhet på arbetsplatsen.

Goda och rättvisa villkor och en bra arbetsmiljö är en förutsättning för fortsatt hög produktivitet, ett högt arbetskraftsdeltagande och en hög sysselsättningsgrad bland både kvinnor och män. Detta gäller för såväl dem som är yrkesverksamma som dem som håller på att etablera sig på arbetsmarknaden.
Det omfattar arbete inom både traditionella yrken och nya branscher samt under nya former.

Under Sveriges ordförandeskapsår kommer behovet av ordning och reda på den nordiska arbetsmarknaden att uppmärksammas. Ett expertseminarium kommer att anordnas i Stockholm den 24 augusti 2018, där nordiska erfarenheter av arbetet med att motverka fusk och arbetslivskriminalitet samt att skapa förutsättningar för sund konkurrens i arbetslivet kommer att vara i fokus. Expertseminariet kommer att kopplas ihop med pågående nordiska samarbeten inom området.

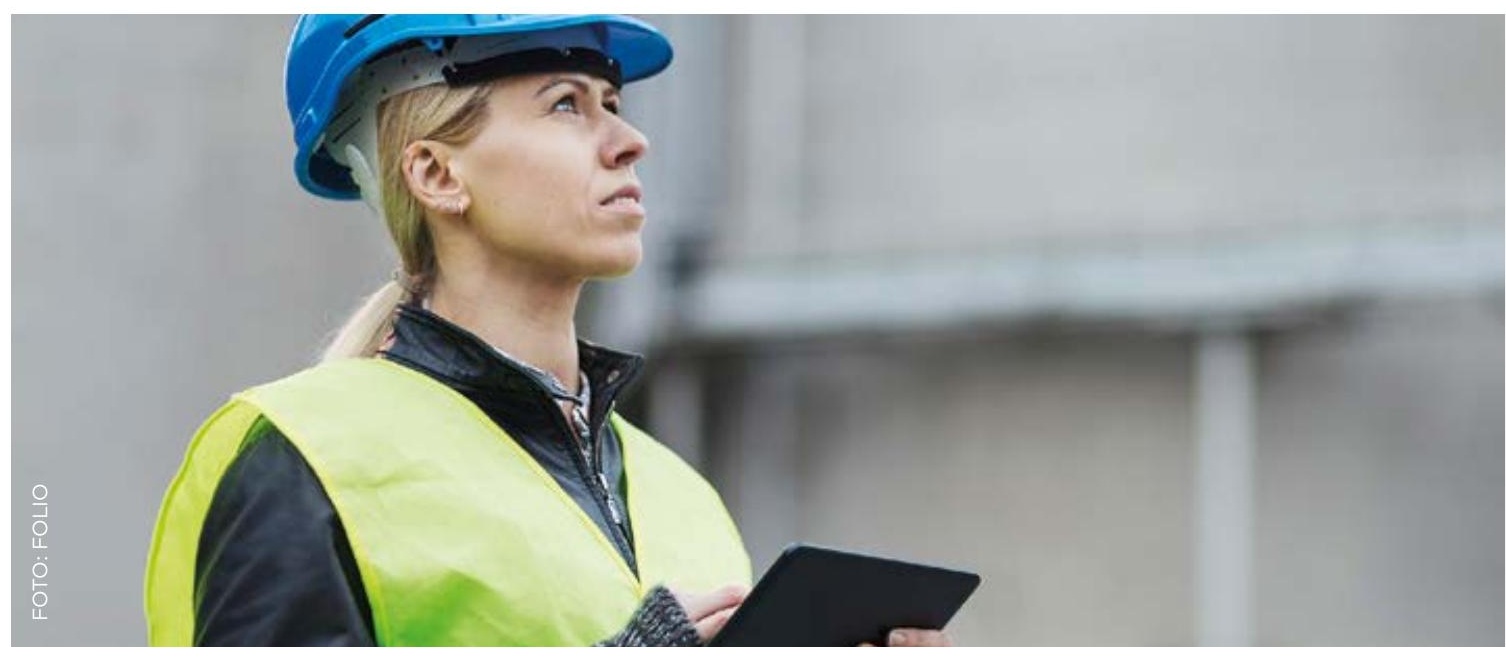




\section{Den vuxna befolkningens kunskaper och kompetens}

Uppfyller den vuxna befolkningen nuvarande och framtida behov av kompetens? Det är något som har studerats i det OECD-initierade programmet PIAAC. ${ }^{1}$ De första resultaten från den internationella undersökningen av vuxnas färdigheter publicerades 2013.

Forskare, statistikproducenter och experter från nationella vuxenutbildningsinstitutioner i Norden har med hjälp av finansiering från Nordiska ministerrådet kunnat etablera ett särskilt nätverk för PIAAC. Detta nätverk har bland annat tagit fram en särskild nordisk PIAAC-rapport och skapat en nordisk PIAAC-databas med variabler från undersökningen och från nationella register.
Resultaten från den nordiska PIAACrapporten publicerades 2015 och de visade att de nordiska länderna överlag hade bra resultat när det gäller den arbetsföra befolkningens kunskaper och kompetens, men att det även fanns en relativt stor andel i åldern 16-64 år med låga kunskapsnivåer. Fler nordiska analyser baserat på data från PIAACundersökningen har gjorts under de senaste åren och resultaten från dessa kommer att presenteras och diskuteras på ett expertseminarium som Arbetsmarknadsdepartementet och Utbildningsdepartementet tillsammans anordnar i slutet av 2018.

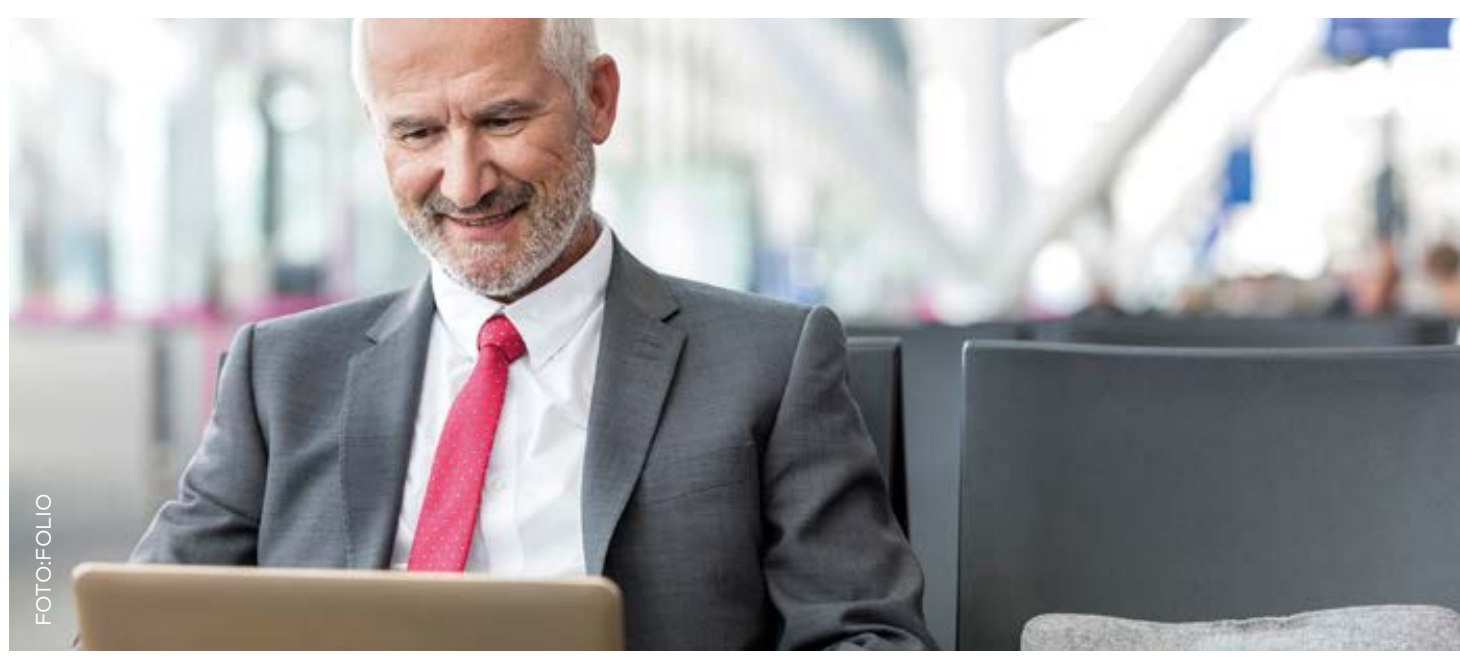

${ }^{1}$ Programme for the International Assessment of Adult Competencies. 


\section{Gränshinderarbetet}

Ett samarbete mellan de nordiska länderna kring gränshinder är viktigt för en väl fungerande arbetsmarknad. Avlägsnandet av hinder ökar möjligheterna för nordbor att arbeta i ett annat nordiskt land och bidrar till en ökad tillgång till arbetskraft och förbättrar matchningen mellan arbetssökande och lediga jobb.
Olika nationella system och regler för arbetslöshetsförsäkringen har dock bidragit till att vissa problem har uppstått för personer som arbetar över gränserna. En översyn av den svenska arbetslöshetsförsäkringen har gjorts under de senaste åren, där även en del gränshinder har varit i fokus. Några av dessa hinder kan troligen få en lösning under det svenska ordförandeskapet 2018.

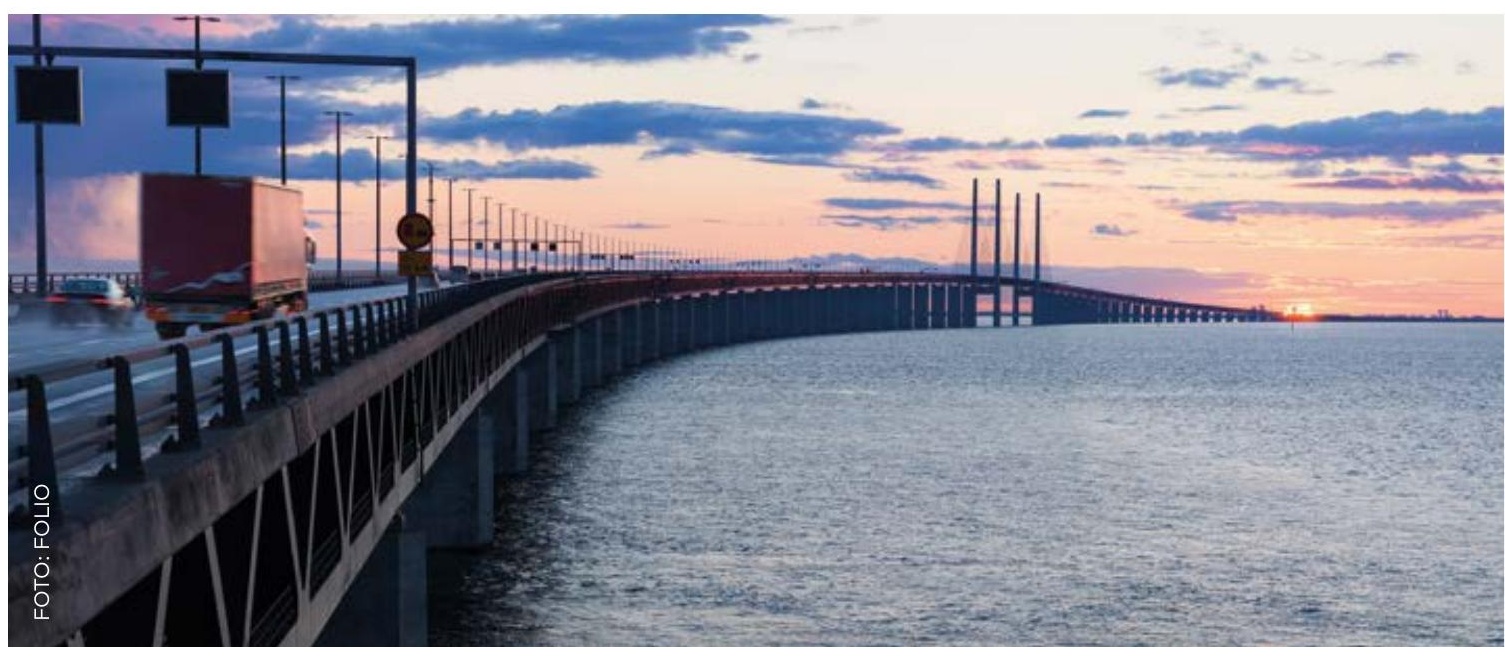




\section{Ett nytt samarbetsprogram 2018-2021}

Under 2017 har ett nytt samarbetsprogram för arbetslivsområdet som beskriver de centrala politiska utmaningar och prioriteringar inom sektorn under perioden 2018-2021 tagits fram. Syftet med samarbetsprogrammet är att fastställa det formella nordiska regeringssamarbetets strategiska fokus. Programmet ger en övergripande beskrivning av insatsområden där konkreta initiativ och projekt kan skapas.

Samarbetet inom arbetslivsområdet omfattar de nordiska länderna samt Färöarna, Grönland och Åland, och avser sysselsättnings- och arbetsmarknadsområdet samt arbetsmiljö- och arbetsrättsområdet. Det nya programmet börjar gälla samtidigt som Sverige övertar ordförandeskapet i Nordiska ministerrådet.

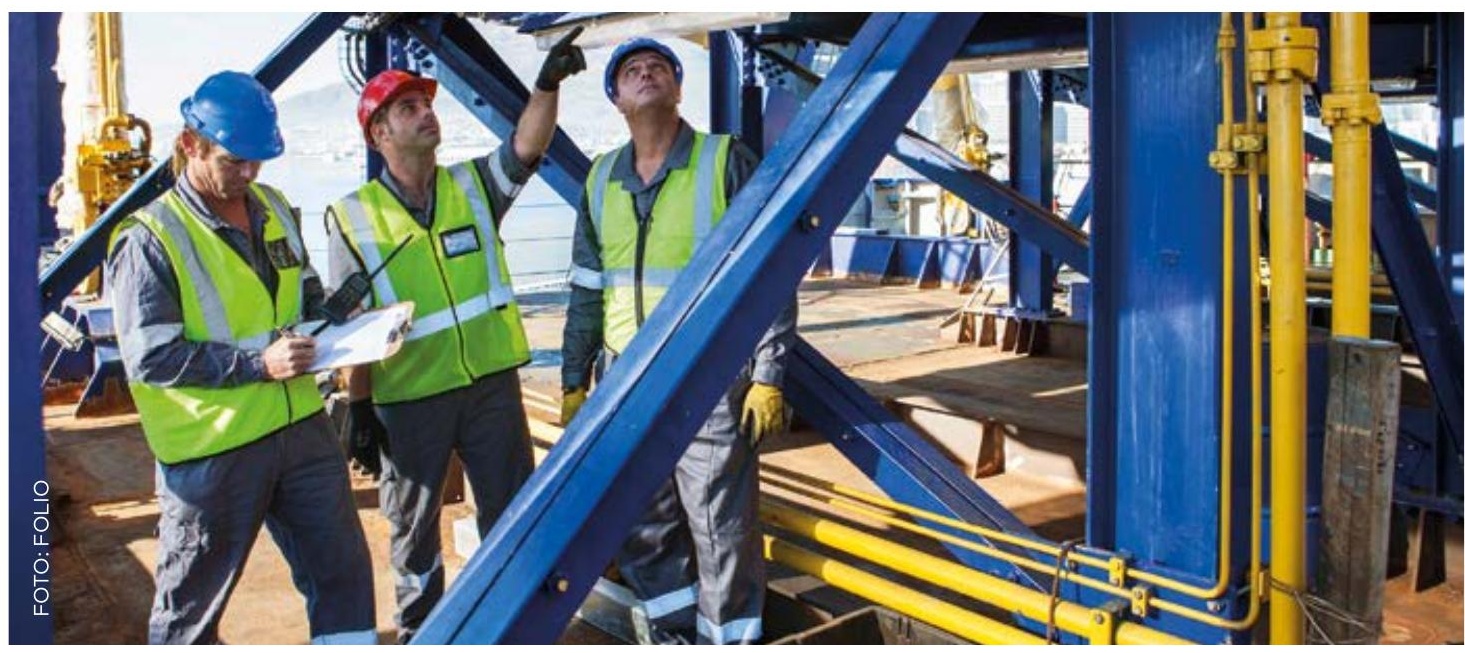




\section{Övergripande fokusområde och samarbetspartners}

Jämställdhetsperspektivet kommer att belysas genomgående under samtliga aktiviteter under ordförandeskapsåret. Under året kommer även en rad samarbeten med andra departement, ministerråd, myndigheter, institutioner, företag, arbetsmarknadens parter och intresseorganisationer i Norden att äga rum.
Nordens välfärdscenter, Norden i Fokus, Nordiska institutionen för vidareutbildning inom arbetsmiljöområdet (NIVA), Svenska ILO-kommittén, Arbetsmiljöverket, Ministerrådet för jämställdhet, Ministerrådet för utbildning och Arbetets museum är några exempel på samarbetspartners.

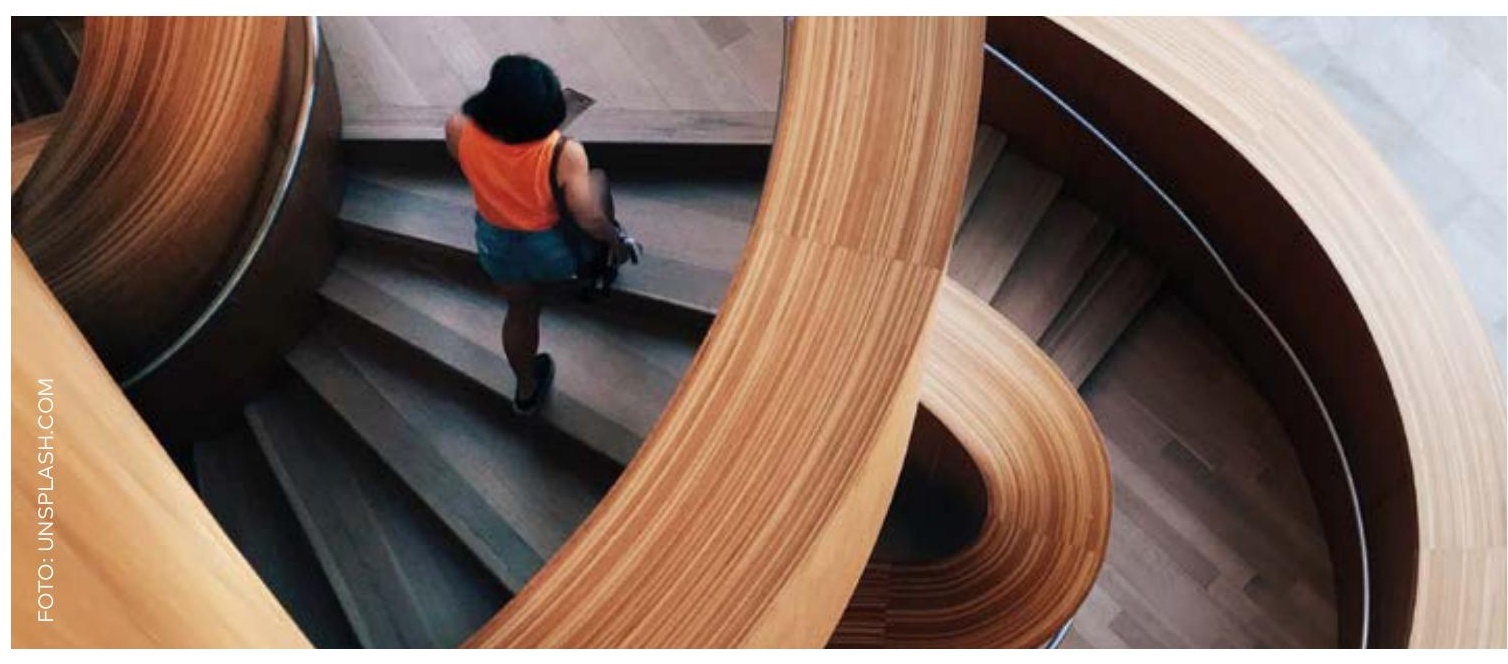




\section{Preliminärt kalendarium 2018}

12-13 april

13 april

15-16 maj

24 augusti

nov/dec
Nordiskt arbetsmarknadsministermöte, Stockholm

Konferens om Etablering på arbetsmarknaden för utrikes födda

Konferens om Framtidens arbetsmarknad

Expertseminarium om Ordning och reda på arbetsmarknaden

Expertseminarium om den vuxna befolkningens kunskaper

och kompetens

Ämbetsmannakommitté- och utskottsmöten

samt möten i arbetsgrupper som leds av Sverige

1-2 mars Arbetsmiljöutskottet, Köpenhamn

5-6 mars

Arbetsrättsutskottet, Danmark

7-8 mars

Arbetsmarknadsutskottet, Stockholm

8-9 mars

Ämbetsmannakommittén för Arbetsliv, Stockholm

våren

Nordisk-baltisk-polska EU-informationsgruppen, Bryssel

hösten

Arbetsmarknadsutskottet

hösten

Arbetsmiljöutskottet

hösten

Arbetsrättsutskottet

hösten

Ämbetsmannakommittén för arbetsliv, Köpenhamn 
Nordisk ministerråd

Nordens Hus

Ved Stranden 18

DK-1061 København K

www.norden.org

ANP 2017:784

ISBN 978-92-893-5277-2 (PRINT)

ISBN 978-92-893-5278-9 (PDF)

ISBN 978-92-893-5279-6 (EPUB) 